\title{
Field Performance and Economic Feasibility of Self-Propelled Vertical Conveyor Reaper (VCR) for Harvesting of Rice in West Sikkim and A Technological Strategy for Mitigation of Air Pollution through Crop Residue Burning in India
}

\author{
Abhijit Debnath $*{ }^{1}$ and Narvendra Singh Chauhan* \\ *Department of Farm Machinery \& Power Engineering, College of Agricultural Engineering \& Post Harvest Technology \\ (Central Agricultural University, Imphal), Ranipool, Gangtok-737135, Sikkim, India \\ †Correspondence author: Abhijit Debnath; abhijit1732@gmail.com \\ ${ }^{1}$ Present Address: Department of Civil Engineering, IIT (BHU), Varanasi-221005, Uttar Pradesh, India
}

Nat. Env. \& Poll. Tech. Website: www.neptjournal.com

Received: 09-08-2019 Accepted: 27-08-2019

Key Words:

Harvesting of rice; Vertical Conveyor reaper; Cost efficiency; Air pollution; Crop residue

\begin{abstract}
Sikkim is a small Indian state located in the Himalayan region with 10.67 thousand hectares under cultivation and rice production of 19.69 thousand tonnes. Mechanized rice harvesting can play a crucial role in reducing grain loss and operational cost. To mechanize rice harvesting in hilly areas, a feasibility study has been undertaken to evaluate the field performance of self-propelled Vertical Conveyor Reaper (VCR) for the harvesting of rice as well as economically in terraces of Daramdin Government farm, Sikkim. In India, out of total 488 MT crop residue, about $24 \%$ of it was burnt in agricultural fields during 2017, resulting in emissions of particulate matter (PM2.5), elemental carbon (EC) and organic carbon (OC) and additionally $\mathrm{CO}_{2}$ equivalent greenhouse gases $\left(\mathrm{CO}_{2}, \mathrm{CH}_{4}, \mathrm{~N}_{2} \mathrm{O}\right)$ were also added to the atmosphere. VCR has been evaluated under the Bureau of Indian Standards (BIS) code in field \& laboratory conditions. The pre and post-harvesting field parameters for operating the VCR have been determined. The field capacity and efficiency of VCR were $0.1203 \mathrm{ha} / \mathrm{h}$ and $72.03 \%$ at $1.52 \mathrm{~km} / \mathrm{h}$, compared to $0.0178 \mathrm{ha} / \mathrm{h}$ in manual operation. At lower speed and better control, terrace-1 losses were $0.58 \%$ less than terrace- 2 . The harvesting cost/ha calculated considering the field capacity was Rs.1140.59/ha (US\$16.44) and Rs. 1368.61/ha (US\$19.73) for gear-1 and gear-2 respectively, which leads to considerable savings in time and labour which was $85.2 \%$ and $30.8 \%$ for the operational cost (gear-1) giving maximum efficiency. Also, instead of manual operation where stubble height remains at $70 \mathrm{~mm}$, VCR harvest the crop at a maximum height of $11-13 \mathrm{~mm}$, which further reduces the crop residue burning in fields and results in mitigation of air pollution. Therefore, in hilly terraces or plane areas where the use of reaper is feasible, its use may be promoted as efficient harvesting and environmental strategy both.
\end{abstract}

\section{INTRODUCTION}

Harvesting of crops is one of the time and labour consuming agricultural operations in peak harvesting season to get maximum return and minimum losses. Mechanical harvesting of all most all cereal crops is a challenging problem in India and tropical countries as India has good potential for increasing production, method of harvesting are still primitive, and farmer use hand sickle for this purpose (Tripathi et al. 2018a, Tripathi et al. 2018b). The agriculture status of Sikkim thus remained highly subsistence-oriented. Major obstacles of the State's agricultural development are the limited area of cultivable land, smaller and fragmented land holdings, difficult hilly terrain, and diverse agro-climatic condition prevailing at short distances, low farm income, declining labour availability for agriculture and allied activities, and lack of adequate supportive infrastructures (FS \& ADD 2016). Further, its dependence on traditional methods has made the cost of cultivation very high in Sikkim. Topography and climatic condition of the state are favourable for agriculture and horticulture in the state as different principal crops grown in Sikkim are: wheat, paddy, maize, barley, buckwheat, cardamom, potato, tea, etc. In Sikkim, the cultivation is carried out in two conditions namely in terraces and valleys. The area occupied under rice cultivation and production in 2013-14 was 11040 hectares and 20.18 MT respectively and while from $2012-13$ to $2015-16$ the production was subsequently decreased from 21.34 MT to 19.69 MT.

It is the fact that crop productivity of any region highly depends on the farm power availability. In Sikkim, most of the field crops are cultivated either in sloping fields or in narrow terraces. The farm mechanization in Sikkim is almost non-existent and mainly depends on human and draft animal. Due to very steep slopes, the terraces are narrow and at times with a vertical interval of nearly 6 to 7 feet. Even scope for the use of conventional power tillers (Rated power 8 to 10 
$\mathrm{kW}$; Weight 200 to $400 \mathrm{~kg}$ ) is limited to a few pockets of West Sikkim. The use of a machine of large size is not feasible due to the narrow and non-uniform width of terraces and the heavy weight of the machine.

Tillage, inter-culture and sowing equipment are specific to the type of land and those designed for plain lands does not necessarily suit to hill agriculture. The soil of Sikkim is mostly rocky and is also prone to landslide. Therefore, there arises a need to tackle these difficulties by carrying out various possible solutions. Despite excellent climatic conditions, abundant rainfall, and fertile soil (high organic content) of the region, the productivity of different crops is much lower as compared to national productivity level. Further, manual harvesting of crop requires considerable labour and time. Harvesting, threshing, and transplanting consume about 70 per cent of the total labour requirement (Kumar et al. 2013). Harvesting operation alone consumes 20 per cent which includes harvesting by sickles and bundle making (Dutt \& Prasad 2002). During harvesting season, sufficient labourers are not available, and this leads to delayed harvesting and thus resulting in considerable losses of the crop. Therefore, mechanizing the harvesting, through the introduction of the self-propelled machine is one of the alternatives to tackle the problem, and reduce grain losses due to delayed harvesting and save the duration of harvesting. Where government have adopted and promoted combines for harvesting, but due to large quantity of straw handling after harvesting and disposal of waste products creating environmental pollution by burning in the field to prepare for next season. On the other hand, reaper harvesters are other alternative harvesting equipment.

The present study addresses the relevance of Vertical Conveyor Reaper in the agricultural development of the state. Researchers have analysed for different width of cut and field grain yields and at what width of cut the costs of complete machine are reaping with manual gathering would be equal to those of manual harvesting (Garg et al. 1984, Guruswamy et al. 1996). Reaper performance in relatively high working speed, giving it an overall reaping output of about $0.35 \mathrm{ha} / \mathrm{h}$ for $1.6 \mathrm{~m}$ wide cut and other three reapers, two were of $1 \mathrm{~m}$ cut, and the other was $0.5 \mathrm{~m}$ cut (Prasad et al. 1992). The effective field capacity of reaper was 0.43 ha/h using gear combination II with $76 \%$ field efficiencies (Nadeem \& Gee-Clough 1983). Grain losses in wheat crop harvesting by Sayyed reaper-windrower in two different locations (Malir and Latif farm) were $1.03 \%$ and $1.46 \%$ at different crop moisture levels, and farm losses in machine and manual harvesting are $41.1 \mathrm{~kg} / \mathrm{ha}$ and $84.9 \mathrm{~kg} / \mathrm{ha}$ in case of Malir and Latif farms were $48.0 \mathrm{~kg} / \mathrm{ha}$ and $139.6 \mathrm{~kg} / \mathrm{ha} \mathrm{re-}$ spectively (Bukhari et al. 1991). The crop conditions included crop variety, age of the crop, plant height, plant population, straw grain ratio, moisture content and crop yield an also area harvested, operational speed, working width, stubble height achieved and losses (Kathirvel et al. 2009).

Researchers indicated that self-propelled vertical conveyor reaper windrowers are suitable for harvesting crop with low plant population, plant height, crop canopy and low yield levels under rainfed conditions (Alizadeh et al. 2007, Bansal \& Sakr 1992, Gill et al. 2018). Three different combined performances in terms of harvesting time, grain losses, fuel consumption, the energy required and total cost were compared and found that field efficiency of $70.5 \%$ at speed about $4.0 \mathrm{~km} / \mathrm{h}$ and grain moisture content of $22 \%$ (Badr 2005). The parameters that were used to measure during crop harvesting as follows-(1) speed of travel (2) time losses and effective operating time (3) field efficiencies (4) effective field capacity (5) harvesting loss (6) harvesting cost. Front-mounted NDUAT (Narendra Deva University of Agriculture Technology, Faizabad, India) vertical conveyer reaper was compared with the conventional method regarding field capacity, forward speed and manpower for harvesting in hilly areas. The capacity of the machine at the farm was observed $93 \%$ more than the manual harvesting $(0.009 \mathrm{ha} / \mathrm{h})$ and saved $35 \%$ cost of operation with two times labour (Singh et al. 2007). Improvements and assessment are required due to inherent shortcomings like the drudgery of operation and non-suitability to harvest taller food crops that increase the utility of reaper (Singh et al. 2008). The field capacity of harvesting paddy through VCR was $0.3 \mathrm{ha} / \mathrm{h}$ with $73 \%$ at speed $3.2 \mathrm{~km} / \mathrm{h}$ and $5.5 \mathrm{~L} /$ ha fuel consumption respectively. Manual harvesting was Rs. 400/ha (US\$5.77) costlier than mechanical harvesting (Manjunatha 2009). Performance evaluation of VCR was carried for wheat crop varieties WH 147 and HD 2189 with BIS test code procedure. The header loss, conveying loss, and total machine losses were $0.85 \%$, $3.1 \%$, and $3.95 \%$, respectively. The cost of the harvesting with the straight-line method was found to be Rs. 677.50 / ha (US\$9.77) with field capacity $0.13 \mathrm{ha} / \mathrm{h}$, saving up to 44 per cent cost of harvesting (Kurhekar \& Patil 2011). The harvesting for Finger millet (Eleusinecoraconagaertn) in the GKVK (Gandhi Krishi Vignana Kendra), Bangalore with four different commercial reapers viz. Sharchi, Fortune, KAMCO (Kerala Agro Machinery Corporation Ltd., India) and Vinayaka make power tiller reaper attachment was carried out while it is better by using the Shrachi reaper fitted with 24 cutting blades optimized with $90 \mathrm{~cm}$ cutting width. The minimum and satisfactory harvesting stubble height of 8-9 cm with negligible shattering losses observed by using Shrachi reaper compared to other reapers. Feasibility study of such equipment is required before their promotion for the harvesting of crops in the hilly region. 
Biomass burning is an important source of aerosol and gaseous pollutants in the atmosphere, other than industrial and vehicular emissions having a potential impact on global air quality and climate chemistry (Andreae 1991, Levine et al. 1995, Andreae \& Merlet 2001, Yang et al. 2008). Open biomass burning is a global practice to incineration of living and dead vegetation for land clearing and change land-use patterns. According to recent reports, around $730 \mathrm{Tg}$ of biomass is burned annually from both natural and anthropogenic sources in Asia, of which 18\% is contributed by India which also includes forest fires, grassland fires, and crop residue burning in agriculture field (Streets et al. 2003a, b). A study by Jain et al. (2014) and Venkataraman et al. (2006) also found that nearly $18-30 \%$ of the residue is burned in agricultural fields in India. According to National Policy for Management of Crop Residues (NPMCR) 2014 report, Ministry of Agriculture, Government of India crop residue generated in Sikkim is around 0.15 MT, residue surplus is $0.02 \mathrm{MT}$, residue burned 0.01 MT. In-situ crop residue burning is practiced not only in India but also worldwide (McCarty et al. 2009, Chen et al. 2017) despite having detrimental effects on air quality and human health. Hence, there is a need to understand pollutants emanated from crop residue burning can also affect properties, materials and human health when they are inhaled, causing respiratory problems (Schwartz 1993, Godish 1997, Mohanraj \& Azeez 2004, Thaller et al. 2004, WHO 2004, Pandey et al. 2005).

\section{Air Pollution From Crop Residue Burning}

During harvesting periods, open burning of agricultural crop residues leads to emission of a large amount of air pollutants such as particulate matter (PM10, PM2.5, PM1), trace gases [carbon monoxide $(\mathrm{CO})$, ammonia $\left(\mathrm{NH}_{3}\right)$, sulphur dioxide $\left(\mathrm{SO}_{2}\right)$ ], greenhouse gases (GHGs) [carbon dioxide $\left(\mathrm{CO}_{2}\right)$, oxides of nitrogen (NOx), methane $\left(\mathrm{CH}_{4}\right)$, ozone $\left(\mathrm{O}_{3}\right)$, elemental carbons (EC), organic carbons (OC), along with volatile organic compounds (VOCs) to the atmosphere (Ravindra et al. 2019a, Duan et al. 2004, Lemieux et al. 2004). As many developed countries have banned but it is still a prevailing practice in developing countries to burn the residue due to poor crop residue management (Ravindra et al. 2019a). Also, air quality is significantly affected because of agricultural field burning during the harvest period (Mittal et al. 2009). Witham \& Manning (2007) showed that the impact of transport of pollutants during agricultural residue burning on a regional scale of air pollution.

Pollutants emission from crop residue burning and their dispersion varies according to seasons, atmospheric meteorology, and types of agricultural residue which could potentially affect biogeochemical cycles and climate change (Kaskaoutis et al. 2014, Sen et al. 2017, Ramanathan et al.
2005, McNeill 2017). The declining air quality is a great concern due to residue burning in the rural areas which harm human health and the environment, and there is a need to minimize the dispersion of burning emissions in the atmosphere (Awasthi et al. 2011, Ravindra et al. 2016a). Technological improvements in the agricultural sector and the use of modern agricultural practices can minimize the production of crop residue from rice harvesting (Ravindra et al. 2019a).

In the background of the above, the present study has been undertaken to evaluate the field performance and economic feasibility of Self-Propelled VCR $(3.64 \mathrm{~kW})$ for the harvesting of rice as well as to corporate a technological strategy to mitigate air pollution by burning paddy crop residues.

\section{STUDY AREA}

The present study is covering the Daramdin village located in Himalayan State of Sikkim the north-eastern part of India, covering coordinates of $27.31^{\circ} \mathrm{N}$ latitude and $88.30^{\circ} \mathrm{E}$ longitude. Daramdin has an average elevation of $1246 \mathrm{~m}$. The average annual temperature of Sikkim is around $18^{\circ} \mathrm{C}$. Fig. 1 depicts the map of CAEPHT, Ranipool and also it includes the area of the Daramdin farm where the performance evaluation of VCR has been undertaken.

\section{MATERIALS AND METHODS}

This includes the materials used and methodology followed for evaluating the performance of the commercially available self-propelled vertical conveyer reaper (walking type). The field evaluation of the machine has been undertaken in the laboratories of CAEPHT and Daramdin Government Farm. The details of the machine and other instruments used and methodology adopted is discussed under the following heads.

(a) Brief description of the machine

(b) Instruments used for performance evaluation

(c) Laboratory testing procedure [IS: 11467-1985 (Reaffirmed in 2012)]

(d) Field evaluation procedure [IS: 11467-1985 (Reaffirmed in 2012)]

(e) Cost analysis procedure [IS:9164-1979 (Reaffirmed in 2002)]

(f) Reason and consequences of stubble burning

\section{Brief Description of Self-Propelled Vertical Conveyor Reaper (VCR)}

Self-propelled VCR is a commercially available engine operated self-propelled machine (walk-behind type) used for harvesting cereal crops. It consists of crop row divider, 


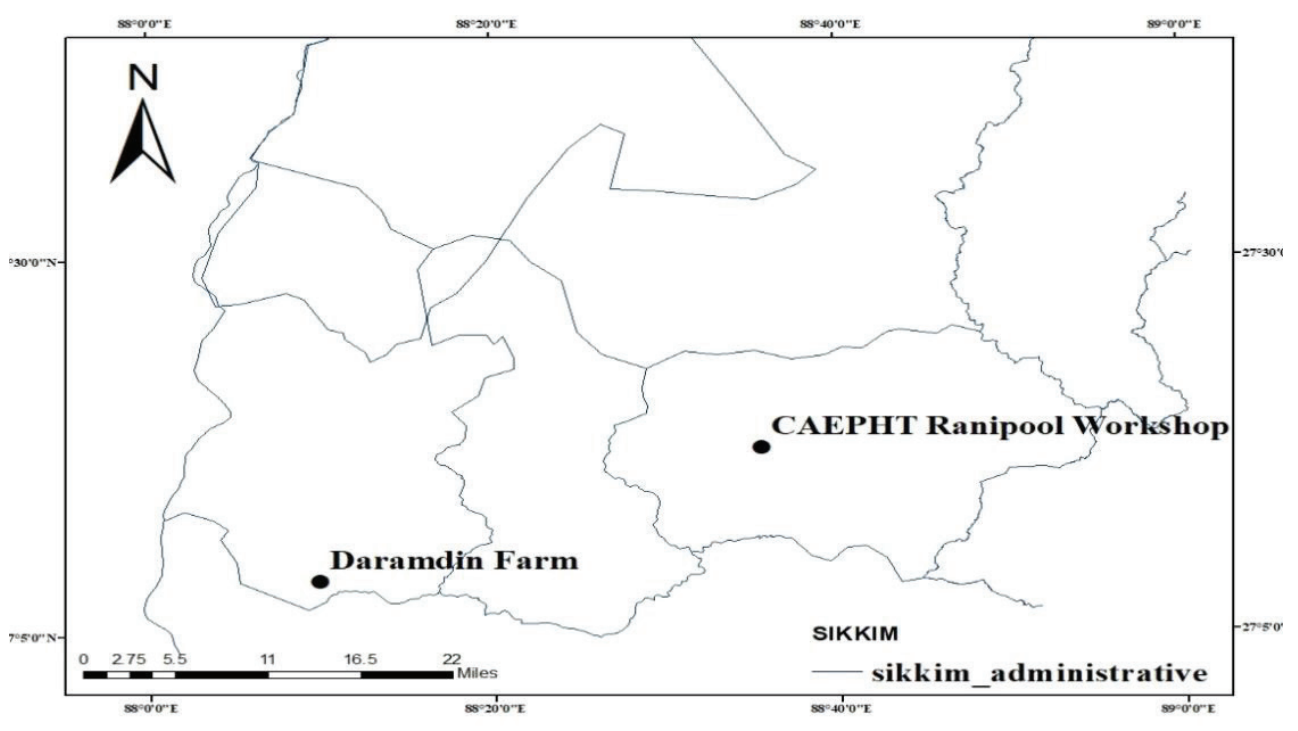

Fig. 1: Laboratory and field evaluation locations in Sikkim.

star wheel, cutter bar, and a pair of lugged conveyor belts and a handle fitted with clutch and brakes, engine, power transmission box, lugged wheels, crop row dividers, conveyor, star wheels, operating controls, and a sturdy frame. The machines cut and convey the crop vertically to one side and windrow the crops on the ground uniformly. Collection of crops for making bundles is done manually. The engine power is transmitted to cutter bar and conveyor chain through chain pulleys. The crop row dividers are provided with star wheels which help in lifting, gathering and guiding the crop towards the cutter bar, where reciprocating action of cutter bar cuts the crop stems. After the crop is cut, it is held in a vertical position during its passage employing pressure springs and star wheel against the vertical frame of the reaper. The vertically-held crop is then delivered one side of the machine by two lugged chain conveyors (one close to the cutter bar and the other at the upper end) and falls on the ground in the form of a fine-windrow perpendicular to the direction of the movement of the machine (El-Sharbasy 2006, Nadeem et al. 2015). It helps in easy collection of crops manually and saves labour for bundling operation.

\section{Instruments and Other Items Used}

During laboratory testing for its functionality and performance evaluation of the machine in the field for the harvesting of rice crop, following instruments and other items were used.

1. Measuring scale $(1000 \mathrm{~mm})$

2. Measuring tape $(30 \mathrm{~m})$
3. Tachometer

4. Stopwatch

5. Infra-red moisture meter

6. Hot oven

7. Weighing balance (capacity $=1 \mathrm{~kg}$ and $10 \mathrm{~kg}$ : $\mathrm{LC}=0.001$ $\mathrm{g}$ and $0.5 \mathrm{~g}$ )

8. Measuring cylinder for estimation of fuel consumption

9. Sickle

10. Cleaning brushes

\section{Laboratory Testing Procedure}

The methodology adopted for both the laboratory testing of the Self-Propelled VCR is as per following test codes:

IS: 11467-1985 (Reaffirmed in 2012): Test Code for Cereal Harvesting Machine (IS: 11467-1985, 2012).

The main component of the self-propelled VCR and specification checking: The machine consists of major components of the machine are prime mover, a steering handle, drive wheel, crop divider, star wheel, conveyor chains, and cutter bar (Fig. 2).

The brief specifications of the VST reaper used for performance evaluation are summarized in Table 1.

Material analysis: The hardness and chemical analysis of critical components, such as knife section (IS: 6025-1982) (IS: 6025-1982, 1999), guard and ledger plate (IS : 60241983 ) (IS:6024-1983, 1999) and knife back (IS : 103781982) (IS: 10378-1982, 2001) shall be made and checked as per Bureau of Indian Standards. 


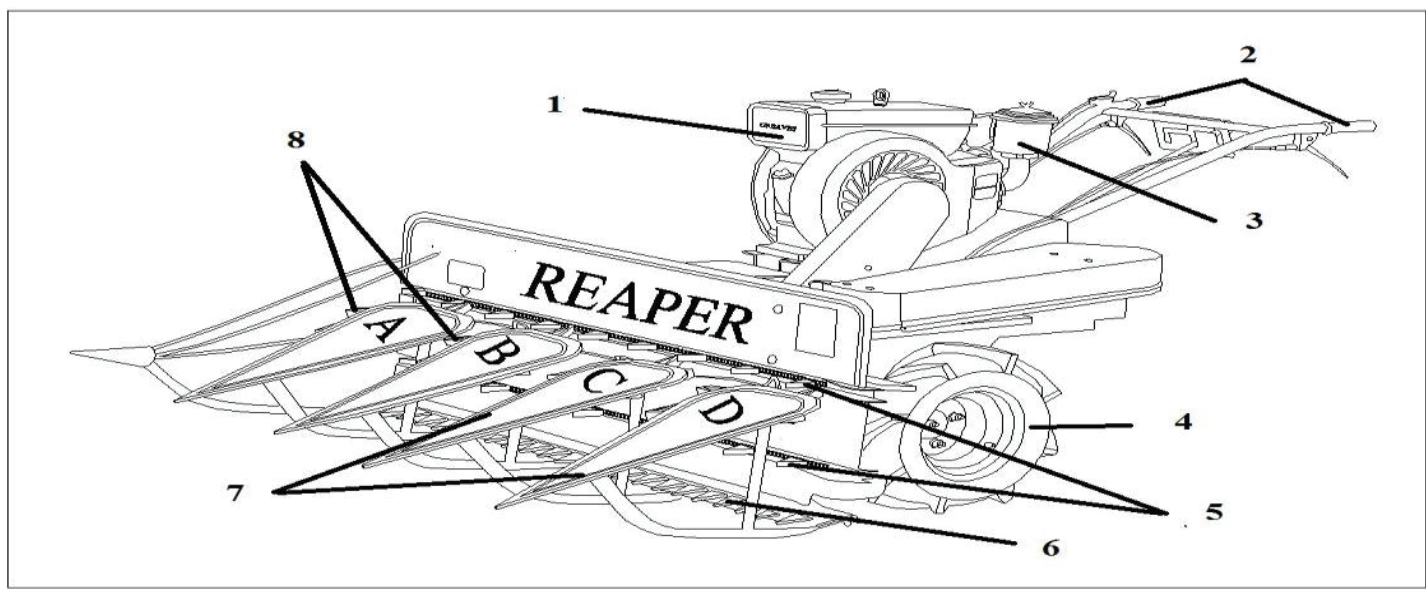

Fig. 2: Schematic diagram of self-propelled VCR showing different components.

$\begin{array}{llll}\text { 1. } & \text { Prime mover } & \text { 2. } & \text { Steering handle } \\ \text { 3. Muffler } & \text { 4. } & \text { Drive wheel } \\ \text { 5. Conveyor chain } & \text { 6. } & \text { Cutter bar } \\ \text { 7. } & \text { Crop divider } & \text { 8. } & \text { Crop guide(star wheel) }\end{array}$

Visual observations and adjustments: The machine was thoroughly inspected and lubricated for its bearings, drives and other moving parts and adjustments of forward speed, ground clearance, wheel track, cutting device, marker etc. as per manufacturer's recommendations and Indian standards.

\section{Field Evaluation Procedure [According to IS: 11467- 1985 (Reaffirmed in 2012)]}

\section{Performance evaluation of vertical conveyor reaper in the}

field: After completion of the laboratory testing successfully, the machine was operated for normal field conditions for rice crops. The testing was conducted in the Govt. Farm at Daramdin, West Sikkim. Fig. 3 depicts the VST model of Vertical Conveyor Reaper and Fig. 4 shows the harvesting operation in Daramdin farm. As per recommendations of the
BIS, following information were recorded.

(a) Field condition: It includes the shape of test field; area of test field; topography of field; type of field; moisture content of soil and frequency of bunds were recorded and reported.

(b) Crop conditions: It includes the name of the crop; the variety of crop; appearance and plant inclination; type of weed present; density of weed; moisture of straw; grain and weeds; crop grain ratio; maturity of the crop (age in days); number of tiller/sq.m; number of grain/ ear head were recorded and reported.

(c) Determination of pre-harvest losses: The pre-harvest losses were determined at three places from the area with one-meter length in the direction of travel and width equal to the full width of the cutter bar. All the loose grain and ear heads are picked up manually.

Table 1: Specifications of the self-propelled VCR.

\begin{tabular}{|ll|}
\hline Manufacturer & VST Tiller Tractors Ltd. \\
\hline Model & VS-4PR \\
Size of Reaper $(\mathrm{mm})(\mathrm{L} \times \mathrm{W} \times \mathrm{H})$ & $2200 \times 1520 \times 1100$ \\
Total Weight $(\mathrm{kg})$ & 210 \\
Maximum power $(\mathrm{kW})$ & 4.5 \\
Rated Power $(\mathrm{kW})$ & 3.64 \\
No. of Gears & Forward-2, Reverse-1 \\
Availability & Commercially available \\
\hline
\end{tabular}




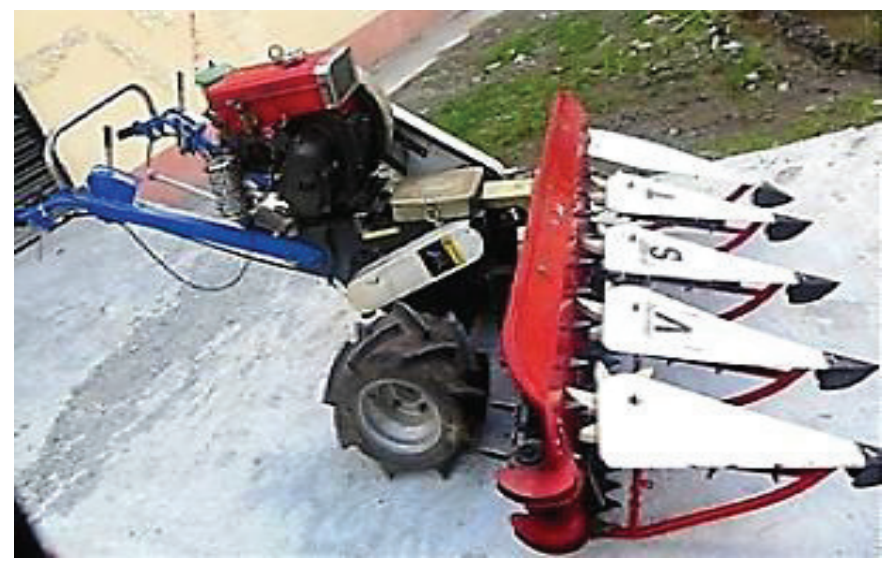

Fig. 3: VST model of VCR.

(d) Field operation: The reaper was operated at uniform forward speed with full cutter bar and observations such as cutting width; cutting height; post-harvest losses (cutter bar +conveyance); condition of windrows; forward speed; area covered; fuel consumption, etc. were recorded in the datasheet.

(e) Ease of operations and adjustment: During field test ease of operation, operators' comfort, accessibility of controls and adjustments were noted down and reported.

(f) Defects; breakdowns and repairs: During field operation, the defects observed were noted down and reported. Any breakdown occurred during field test and replacement of any parts/components and repair underwent were noted down and reported.

(g) Labour requirement and cost of operation: Number of workers and man-hour required for side cutting as well as the cost for harvesting were recorded.

As stated earlier the preliminary testing of self-propelled VCR was carried out in the laboratory. Also, the machine was operated at the field of Govt. Farm Daramdin, Sikkim) as the terraces of the farm are wider and thus better suited for operation of VCR. The performance evaluation of the machine for the harvesting of rice was undertaken in two terraces. The side crops of the terrace of about $500 \mathrm{~mm}$ width were harvested manually to enable the smooth operation of the reaper and windrowing of harvested crops. Samples of the crop were marked with a square of $1 \mathrm{~m}$ side and harvested manually for estimation of various parameters such as grain yield, straw-grain ratio etc. During the field operation of the machine, observations such as the speed of operation, width

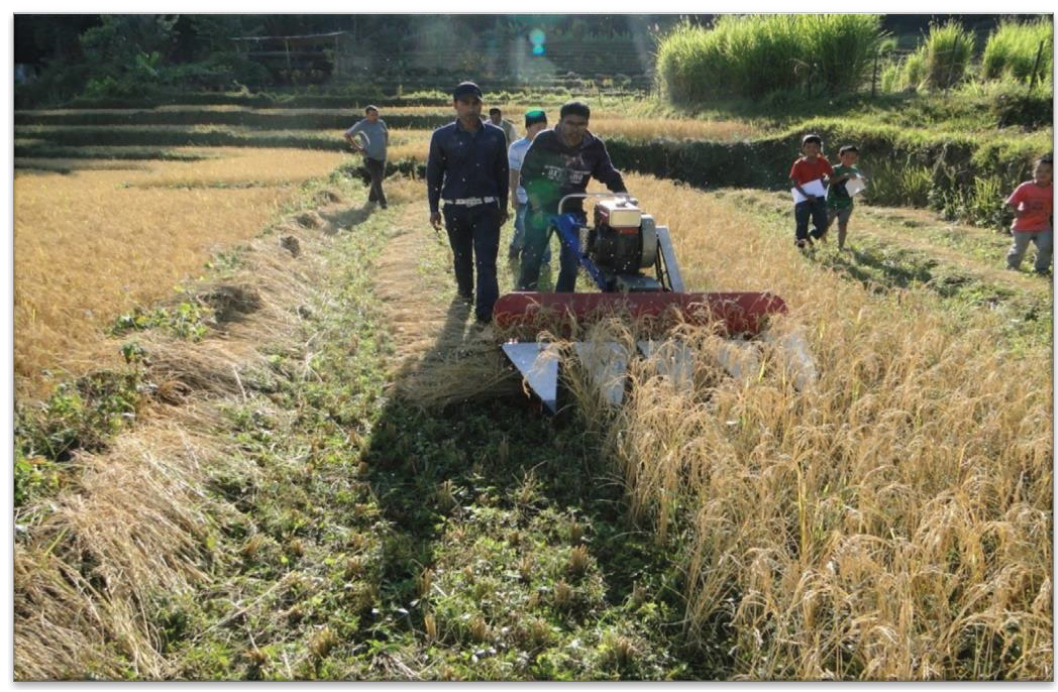

Fig. 4: Harvesting operation with VCR on terrace-1. 
of operation, time taken to harvest the terrace area and fuel consumption were recorded. Using the above observations, the following parameters were computed for the machine.

(a) Speed of operation (forward speed): To estimate the forward speed of the machine while harvesting, the time taken for covering $10 \mathrm{~m}$ was recorded and the speed of travel was calculated.

(b) Time losses and effective duration of operation: Time losses while harvesting crop is the time for adjustments, turning, fuelling, etc. The start and finish time of harvesting in each plot were also noted.

(c) Field capacity: It is the average rate of area harvested. It is two types: (i) Theoretical field capacity and (ii) Actual/ Effective field capacity.

(i) Theoretical field capacity (TFC): Theoretical field capacity is the average rate of area coverage by machine when the machine doing its intended function at the rated speed and width utilized. The theoretical field capacity was calculated by the following equation:

$$
T F C=\frac{W \times S}{10} \mathrm{ha} / \mathrm{h}
$$

Where,

$\mathrm{W}=$ Rated width of the implement in meters $(\mathrm{m})$ $\mathrm{S}=$ Speed of travel $(\mathrm{km} / \mathrm{h})$

(ii) Effective field capacity (EFC): Effective field capacity is the actual rate of performance of land or crop processing in a given time, based on total field time. Actual field capacity was the actual average rate of field coverage by the amount of actual time (lost + productive time) consumed in the cutting operation. The effective field capacity was calculated using the following equation:

$\operatorname{EFC}(\mathrm{ha} / \mathrm{h})=[$ area covered(ha)/time(h) $]$

(d) Field efficiency (FE): Field efficiency is the ratio of effective field capacity to the theoretical field capacity and determined by the following equation

Where,

$$
\mathrm{FE}=\frac{\mathrm{EFC}}{\mathrm{TFC}} \times 100
$$

TFC $=$ Theoretical Field Efficiency (ha/h)

EFC - Effective Field Efficiency (ha/h)

(e) Harvesting losses: Harvesting losses includes-(i) Uncut losses (ii) Pre-cutting losses, and (iii) Shattering losses.

(i) Un-cutting losses: Un-cutting losses were obtained by collecting un-cutting crop by sickle for each plot area. The total samples were collected and threshed manually, and then the cleaning grains were weighted. The percentage of un-cutting losses was calculated by using the following equation:

Un-cutting losses $(\%)=\frac{\text { un }- \text { cutting losses } / \text { ha }}{\text { total yield } / \text { ha }} \times 100$

(ii) Pre-cutting losses: Pre-cutting losses were obtained by dividing each plot in four parts with the use of a wooden frame of $1 \mathrm{~m} \times 1 \mathrm{~m}$ dimensions, all the grains which fell within the frame are collected and weighed, and the mean of the measured values are recorded. The percentage of pre-cutting losses was calculated by using the following equation:

Pre-cutting losses $(\%)=\frac{\text { Pre }- \text { cutting losses } / \text { ha }}{\text { total yield } / \text { ha }} \times 100$

(iii) Shattering losses: Shattering losses were obtained by locating a frame of the square meter on the ground after cutting the crop by machine, and then the grain losses in the frame represent pre-cutting and operating losses together. Then, for indicating the operating losses or shattering losses only, the pre-cutting losses must be subtracted. The percentage of shattering was calculated by using the following equation:

Shattering losses $(\%)=\frac{\text { Shattering losses } / \text { ha }}{\text { total yield } / \text { ha }} \times 100$

(f) Total grain losses: The percentage of total grain losses was calculated by using the following equation:

Total grain losses $(\%)=($ pre-cutting + un-cutting + shattering) losses

(g) Moisture Content of the crop: The moisture content of the grain, straw and soil were measured using oven drying method and an infrared moisture meter. And it is calculated by using the equation.

$$
\begin{gathered}
\text { MC (\%Wet basis) } \\
=\frac{\text { weight of the water content in the product }}{\text { Total weight of the product sample }} \times 100
\end{gathered}
$$

Where, MC (\% Wet basis) = Moisture content of the sample in percentage weight basis.

\section{Cost Analysis Procedure}

The total cost of harvesting of Self Propelled VCR is estimated by referring to the Indian Standard Code i.e. IS: 9164- 
1979 (Reaffirmed in 2002) [IS: 9164-1979, 2002]. Under these standards, the various cost factors include variable cost and fixed cost.

Fixed costs: (a) Depreciation: This component of cost reflects the reduction in the value of a machine with use (wear) and time (obsolescence). While actual depreciation would depend on the sale price of the machine after its use, based on different computational methods depreciation can be estimated. The following formula based on the straightline method.

Where,

$$
\mathrm{D}=\frac{P-S}{L}
$$

$\mathrm{D}=$ depreciation cost

$\mathrm{P}=$ purchase price of the machine (Rs/annum)

$\mathrm{S}=$ residual value of the machine i.e $5 \%$ of the purchase price.

$\mathrm{L}=$ useful life of the machine in years

(b) Interest on investment: Annual charges of interest may be calculated by the actual rate of interest payable. If the previous instalment is not available, 12 per cent of the average purchase price may be taken. The following formula shall calculate the average purchase price:

$$
A=\frac{P+S}{2}
$$

Where,

$\mathrm{A}=$ average purchase price (Rs)

$\mathrm{P}=$ purchase price of the machine $(\mathrm{Rs})$ and

$\mathrm{S}=$ residual value of the machine ( $5 \%$ of $\mathrm{P}$ )

(c) Insurance and Taxes: Actual amount paid annually for insurance and annual taxes, if any should be charged. If not available, it may be calculated by 2 percent of the average purchase price of the machine per year.

Variable costs: (a) Fuel: Fuel consumption depends on the size of the power unit, load factor, and operating conditions. While the machine is working, the actual oil consumption should be recorded or may be taken from the results obtained at official testing stations. The following formulae can also estimate average fuel consumption:

$$
\mathrm{A}=0.15 \times \mathrm{B}
$$

Where,

$\mathrm{A}=$ average diesel consumption in $\mathrm{L} / \mathrm{h}$,

$\mathrm{B}=$ rated power in $\mathrm{kW}$.

(b) Lubricating oil: While the machine is working, the actual oil consumption should be recorded. In case oil consumption data is not available, oil consumption may be taken as 2.5 to 3 per cent of the fuel consumption on a volume basis.
The cost of filters, replacement of oil, and other lubricants are included under repairs and maintenance.

(c) Repair and Maintenance: The accumulated repair and maintenance costs (TAR) at any point in a machine's life can be estimated from the following formulae:

For self-propelled machine, reaper,

$$
\mathrm{TAR}=0.096 \mathrm{X}^{1.4}
$$

Where,

TAR = Total Accumulated Repair Cost divided by the purchased price of the machine expressed as a percentage, and

$X=100$ times the ratio of the accumulated hours of use to the wear-out life.

(d) Wages and Labour Charges: The wages and labour charges varied from person to person and prevailing rates in the region. The average cost per hour may be computed by dividing the total cost by the number of hours the operator has performed the work.

Total cost per hour: The sum of fixed cost, variable cost per hour gives the total operating cost of the machine for the harvesting of rice in terraces.

Total cost per hectare: The total cost per hectare may be obtained based on the actual field capacity of the machine with the use of the operating cost of the machine and actual field capacity of the machine. The value of harvesting one hectare with VCR may be compared with that of the traditional method of harvesting of rice crop in the region.

\section{Reason and Consequences of Rice Crop Residue Burning}

\section{Reasons for stubble burning of rice crop:}

(a) Mechanization has tremendously increased due to the Scarcity of labour for manual harvesting and their increasing wage rates.

(b) Due to shortened intervals between multiple cropping and seedbed preparation, urgent clearing of stubble is needed.

(c) To Control weeds, insects, disease sand pest availability of $\mathrm{N}, \mathrm{P}$ and $\mathrm{S}$ in the soil for a shorter time.

(d) Poor storage facilitiesand higher diesel cost in trolley transportation and availability of crop residue market.

\section{Consequences of Rice Crop Residue Burning}

(a) Rise of global warming due to the emission of GHGs.

(b) The liberation of soot particles and causing smog in the environment (Lohan et al. 2018).

(c) Emissions of harmful air pollutants cause a serious threat to the health hazards of human, animal, and birds 
(Lohan et al. 2018).

(d) Loss of carbon-nitrogen and sulphur present in straw are entirely burnt and lost to the atmosphere burning and deteriorate soil fertility (Lohan et al. 2018).

\section{RESULTS AND DISCUSSION}

The performance evaluation results of self- propelled vertical conveyor reaper (VCR) obtained under laboratory and field conditions are discussed in three stages. The functionality of the VCR was tested in the laboratory conditions in the CAEPHT, and then its performance evaluation for harvesting the rice crop was undertaken in the field of Daramdin in November 2013.

\section{Laboratory Test}

Under laboratory conditions, the machine was tested for its functionality, and relevant data collected during the laboratory tests were included in this section. The forward speed of the machine was measured in a different gear, and throttle settings of the machine (gear- 1 and gear- 2 with respect to $50 \%$ and $75 \%$ throttle settings) and the results recorded are summarized in Table 2.

As per the observations, the comfortable speeds for the operation was $1.86 \mathrm{~km} / \mathrm{h}$ and $2.51 \mathrm{~km} / \mathrm{h}$ recorded at gear- 1 $(50 \%$ and $75 \%)$ for gear- $2(50 \%$ throttle valve). At the higher speed, the vibration of the machine and the noise produced were higher and inconvenient for the operator to handle it and lower speed would affect the field capacity and thereby result into a higher cost of operation.

\section{Crop Parameters}

The details of the crop, on which the performance of the ma- chine was evaluated, are recorded and summarized in Table 3 .

The harvesting of rice crop (variety: Panth-12) grown in two terrace plots were 287.66 and $252.86 \mathrm{~m}^{2}$ areas. The average heights of the crop for terrace 1 and terrace 2 were in the ranges of 850 to $1250 \mathrm{~mm}$ and 700 to $900 \mathrm{~mm}$ respectively. The age of the crop at the time of harvesting was 110 days. The average number of hills per square meter of terrace- 1 and terrace-2 were 45-55 and 40-50 respectively. The average moisture contents of the grain were found to be $16.26 \%$ (wet-basis) and $15.71 \%$ (wet-basis) for terrace 1 and 2 respectively.

\section{Manual Harvesting}

To get the reference data for comparing various parameters for evaluating the performance of the machine, the crop was harvested manually, and relevant data were recorded and summarized in Table 4.

The average weight of the crop grain per square meter was $0.76 \mathrm{~kg}$ and $0.73 \mathrm{~kg}$ for the terrace 1 and 2 respectively. It is evident from Table 4 that the grain yield of terrace 1 and 2 was $3400 \mathrm{~kg} / \mathrm{ha}$ and $3000 \mathrm{~kg} / \mathrm{ha}$, respectively.

\section{Performance Evaluation of Self-propelled Vertical Conveyer Reaper}

Performance evaluation of self-propelled vertical conveyer reaper for the harvesting of rice crop was undertaken at Daramdin Farm (under Department of FSSandAD) Dist. West Sikkim during November 2013. The performance evaluation was undertaken according to the procedure as per BIS codes. During field evaluation procedure, data related to the field, crop, and machine were recorded and summarized in Table 5.

Table 2: Laboratory speed measurement of self-propelled VCR.

\begin{tabular}{|c|c|c|c|c|c|}
\hline Direction of motion & Engine speed (rpm) & Duration (s) & Distance travelled $(\mathrm{m})$ & Speed $(\mathrm{km} / \mathrm{h})$ & Average Speed $(\mathrm{km} / \mathrm{h})$ \\
\hline \multirow{5}{*}{$\begin{array}{l}\text { Forward } \\
\text { Reverse }\end{array}$} & Gear 2 and $75 \%$ throttle setting & $\begin{array}{l}1: 44: 83 \\
1: 50: 83\end{array}$ & 100 & $\begin{array}{l}3.43 \\
3.25\end{array}$ & 3.34 \\
\hline & Gear 2 and $50 \%$ throttle setting & $\begin{array}{l}2: 17: 79 \\
2: 28: 91\end{array}$ & 100 & $\begin{array}{l}2.61 \\
2.42\end{array}$ & 2.51 \\
\hline & Gear 2 and $25 \%$ throttle setting & $\begin{array}{l}3: 12: 20 \\
3: 21: 15\end{array}$ & 100 & $\begin{array}{l}0.93 \\
0.89\end{array}$ & 0.91 \\
\hline & Gear 1 and $75 \%$ throttle setting & $\begin{array}{l}2: 20: 35 \\
2: 25: 20\end{array}$ & 100 & $\begin{array}{l}2.56 \\
2.47\end{array}$ & 2.51 \\
\hline & Gear 1 and $50 \%$ throttle setting & $\begin{array}{l}3: 10: 21 \\
3: 15: 57\end{array}$ & 100 & $\begin{array}{l}1.89 \\
1.84\end{array}$ & 1.86 \\
\hline \multirow{3}{*}{ Reverse speed } & $75 \%$ throttle setting & $\begin{array}{l}2: 46: 02 \\
2: 64: 12\end{array}$ & 100 & $\begin{array}{l}2.43 \\
2.27\end{array}$ & 2.35 \\
\hline & $50 \%$ throttle setting & $\begin{array}{l}3: 04: 25 \\
3: 06: 12\end{array}$ & 100 & $\begin{array}{l}1.97 \\
1.96\end{array}$ & 1.97 \\
\hline & $25 \%$ throttle setting & $\begin{array}{l}4: 12: 21 \\
4: 17: 70\end{array}$ & 100 & $\begin{array}{l}0.71 \\
0.70\end{array}$ & 0.71 \\
\hline
\end{tabular}


Table 3: Details of crop-related parameters used for harvesting with VCR.

\begin{tabular}{|c|c|c|c|}
\hline S. No. & Parameters & \multicolumn{2}{|r|}{ Observations } \\
\hline 1. & Crop variety & \multicolumn{2}{|c|}{ Panth 12 (PD-12) } \\
\hline 2. & Row to row spacing & \multicolumn{2}{|c|}{ NA (manual planted) } \\
\hline 3. & Age of the crop at the time of harvesting (days) & 110 & \\
\hline \multirow{2}{*}{4.} & \multirow{2}{*}{ Field plots } & & Observations \\
\hline & & First terrace & Second terrace \\
\hline 5. & Average plant height (mm) & $1020 \pm 210$ & $790 \pm 100.02$ \\
\hline 6. & No. of hills/sq. m(No./sq. m) & $45-55$ & $40-50$ \\
\hline 7. & No. of tillers per hill & $10-13$ & $9-11$ \\
\hline 8. & Length of ear head (mm) & $225 \pm 5.8$ & $203 \pm 5.5$ \\
\hline 9. & No. of grains per ear head (cm) & $91 \pm 7$ & $55 \pm 3$ \\
\hline & \multicolumn{3}{|l|}{ Moisture content (\%wet-basis) } \\
\hline \multirow[t]{2}{*}{10.} & Straw & $65.33 \pm 1.32$ & $63.63 \pm 1.70$ \\
\hline & Grain & $16.26 \pm 0.81$ & $15.71 \pm 1.15$ \\
\hline
\end{tabular}

It is evident from Table 5 that effective field capacity of the self-propelled VCR was $0.15 \mathrm{ha} / \mathrm{h}$ at an average operating speed of $1.52 \mathrm{~km} / \mathrm{h}$ when the machine was operated in $1^{\text {st }}$ gear. Time taken to harvest rice crop of terrace 1 (Area: 228.61 sq. $\mathrm{m}$ ) was about $0.19 \mathrm{~h}$ and the fuel consumption of the machine was $0.736 \mathrm{~L} / \mathrm{h}$. In case of terrace 2 , results indicate that in $2^{\text {nd }}$ gear effective field capacity of the machine was $0.117 \mathrm{ha} / \mathrm{h}$ at an average speed of $2.189 \mathrm{~km} / \mathrm{h}$. Time taken to harvest the rice crop (Area: 202.66 sq. $\mathrm{m}$ ) was about 0.22 $\mathrm{h}$ and the fuel consumption of the machine was $0.545 \mathrm{~L} / \mathrm{h}$.

Table 4: Performance data for manual harvesting of rice.

\begin{tabular}{|c|c|c|c|}
\hline S. No. & Parameters & Terrace 1 & Terrace 2 \\
\hline 1. & \multicolumn{3}{|l|}{ Moisture content (\%Wet basis) } \\
\hline \multirow{2}{*}{2.} & -Straw (Wet basis) & $65.33 \pm 1.32$ & $63.63 \pm 1.70$ \\
\hline & -Grains (Wet basis) & $16.26 \pm 0.81$ & $15.71 \pm 1.15$ \\
\hline 3. & Soil moisture content (\%Wet basis) & 29.3 & 27.5 \\
\hline 4. & Variety of crop & Panth 12(PD-12) & Panth 12(PD-12) \\
\hline 5. & Maturity of crop (days) & 110 & 110 \\
\hline 6. & Area of the terrace (sq. m) & 287.66 & 252.86 \\
\hline 7. & Type of weed in the field & $\begin{array}{l}\text { Cyprus sp. (motha), } \\
\text { Cyanodon dactylum (durba), } \\
\text { Echinocholo acrrusgalli (sama grass) }\end{array}$ & $\begin{array}{l}\text { Cyprus rotendum } \mathrm{sp} ., \\
\text { Echinocholoa crrusgalli (sama grass), Spilen- } \\
\text { thus armezera (kooro) }\end{array}$ \\
\hline 8. & Stubble height(mm) & $70.3 \pm 5.7$ & $69 \pm 3.6$ \\
\hline 9. & Plant height (mm) & $850-1250$ & $700-900$ \\
\hline 10. & Length of ear head (mm) & $217.6 \pm 18.6$ & $203 \pm 15.4$ \\
\hline 11. & No. of grain per ear head & $80-110$ & $65-80$ \\
\hline 12. & No. of hills per sq. m & $45-55$ & $40-50$ \\
\hline 13. & No. of tillers per hill & $10-13$ & $9-11$ \\
\hline 14. & Weight of crop per sq. m (kg) & $0.76 \pm 0.015$ & $0.73 \pm 0.015$ \\
\hline 15 & Mass of grain per sq. m $(\mathrm{kg})$ & $0.34 \pm 0.02$ & $0.30 \pm 0.02$ \\
\hline 16. & Straw-grain ratio $(\%)$ & $1.23: 1$ & $1.42: 1$ \\
\hline 17. & Grain yield (kg/ha) & 3400 & 3000 \\
\hline
\end{tabular}


The variations in the effective field capacities of the machine were due to variations in the operating speed of the machine. The theoretical field capacity of the machine for terrace- 1 and terrace- 2 were $0.167 \mathrm{ha} / \mathrm{h}$ and $0.241 \mathrm{ha} / \mathrm{h}$ respectively. The field efficiency of the machine in terrace 1 $(72.03 \%)$ was higher than that of terrace- 2 mainly because at a lower speed, operator's control on the machine was better and this he could operate the machine in a better manner in terrace 1 .

Table 6 gives the data for harvesting losses recorded during the field tests. The measured values of pre-harvest and harvesting losses for $10 \mathrm{~m}$ length in the terraces are summarized here. The pre-harvest losses were neglected in the analysis. The losses (viz. shattering loss, cutter bar loss) were calculated by measuring the width of cut of the machine $(1.10 \mathrm{~m})$ for $10 \mathrm{~m}$ length of the forward direction of the machine. The cutter bar loss, conveying loss, and total machine losses were $0.41 \%, 3.12 \%$, and $3.53 \%$ in terrace- 1 ; where $0.44 \%, 3.67 \%$ and $4.11 \%$ in terrace- 2 respectively.

\section{Cost Analyses}

Using the performance data above and referring the Indian Standard IS: 9164-1979 (Reaffirmed in 2002) the operating cost of the machine for the harvesting of rice was estimated. The fixed and variable costs of the machine for harvesting the rice are given in Table 7. Fig. 5 shows the comparison of the cost of harvesting (Rs/ha) for the machine at gear 1 and 2 and that of manual harvesting.

The comparison of fixed and variable cost for gear- 1 and gear-2 operation are shown in Fig. 6 and Fig. 7 respectively.

With respect to the purchase price, depreciation, interest, shelter, and insurance, the fixed cost of the machine operated

Table 5: Performance data for machine harvesting of rice.

\begin{tabular}{|c|c|c|c|}
\hline \multirow{2}{*}{ Sl. No. } & \multirow{2}{*}{ Parameters } & \multicolumn{2}{|c|}{ Observation } \\
\hline & & $1^{\text {st }}$ gear/terrace 1 & $2^{\text {nd }}$ gear /terrace 2 \\
\hline 1 & No. of operators & 1 & 1 \\
\hline 2 & Duration of test (h) & 0.19 & 0.22 \\
\hline 3 & Forward speed $(\mathrm{km} / \mathrm{h})$ & 1.52 & 2.189 \\
\hline 4 & Area (sq. m) & 287.66 & 252.86 \\
\hline 5 & Area harvested (sq. m) & 228.61 & 202.66 \\
\hline 6 & Effective Working width (m) & 1.10 & 1.10 \\
\hline 7 & Stubble height $(\mathrm{mm})$ & $15 \pm 8$ & $21 \pm 3$ \\
\hline 8 & No. of stoppage (times) & 1 & 3 \\
\hline 9 & Mass of crop per sq. m (kg) & 0.754 & 0.726 \\
\hline 10 & Mass of grain per sq. m (kg) & 0.328 & 0.288 \\
\hline 11 & Crop grain ratio & $1.29: 1$ & $1.52: 1$ \\
\hline 12 & Total Grain yield (kg) & 94.35 & 72.82 \\
\hline \multirow{3}{*}{13} & Moisture content ( $\%$ Wet basis) & & \\
\hline & Grain (\% Wet basis) & $16.26 \pm 0.81$ & $15.71 \pm 1.15$ \\
\hline & Straw (\% Wet basis) & $65.55 \pm 1.32$ & $63.63 \pm 1.70$ \\
\hline 14 & Theoretical field capacity (ha/h) & 0.1670 & 0.241 \\
\hline 15 & Effective field capacity (ha/h) & 0.1203 & 0.092 \\
\hline 16 & Field efficiency (\%) & 72.03 & 38.50 \\
\hline 17 & Fuel consumption $(\mathrm{L} / \mathrm{h})$ & 0.736 & 0.545 \\
\hline \multirow[t]{3}{*}{18} & Crop handled $(\mathrm{kg} / \mathrm{h})$ & 941.64 & 743.29 \\
\hline & Harvesting loss ( $\%$ total grain yield) & & \\
\hline & Pre-harvest loss (\%) & Nil & Nil \\
\hline \multirow[t]{3}{*}{19} & Conveying loss (\%) & 3.12 & 3.67 \\
\hline & Cutter bar loss (\%) & 0.41 & 0.44 \\
\hline & Total losses (\%) & 3.53 & 4.11 \\
\hline
\end{tabular}


Table 6: Harvesting losses (g) for $10 \mathrm{~m}$ of operation.

\begin{tabular}{|c|c|c|c|c|c|c|c|c|}
\hline \multirow{2}{*}{$\begin{array}{l}\text { Sl. } \\
\text { No. }\end{array}$} & \multirow[b]{2}{*}{ terrace } & \multirow{2}{*}{$\begin{array}{l}\text { Time taken } \\
\text { for } 10 \mathrm{~m}(\mathrm{~s})\end{array}$} & \multirow{2}{*}{$\begin{array}{l}\text { Width of } \\
\text { cut }(\mathrm{m})\end{array}$} & \multirow{2}{*}{$\begin{array}{l}\text { Height of stub- } \\
\text { ble }(\mathrm{mm})\end{array}$} & \multicolumn{3}{|c|}{ Losses per width of cut $\times 10 \mathrm{~m}(\mathrm{~g})$} & \multirow{2}{*}{$\begin{array}{l}\text { Total machine } \\
\text { losses for } 10 \mathrm{~m}(\mathrm{~g})\end{array}$} \\
\hline & & & & & Pre-harvest & $\begin{array}{l}\text { Cutter bar (Post + Un- } \\
\text { cut) Loss }\end{array}$ & $\begin{array}{l}\text { Shattering loss in } \\
10 \mathrm{~m} \text { length }\end{array}$ & \\
\hline 1 & 1 & 23.65 & 1.10 & 15 & Nil & 15 & 115 & 130 \\
\hline 2 & 2 & 16.89 & 1.10 & 21 & Nil & 14 & 120 & 134 \\
\hline 3 & 2 & 16 & 1.10 & 23 & Nil & 12 & 123 & 135 \\
\hline
\end{tabular}

in gear-1 was Rs. 48.91/h (US\$0.70) which accounts for $13.67 \%$ of the operating cost of the machine. The total variable cost of the machine (including fuel, oil and lubricants, repair and maintenance cost and operator charges) was Rs. $88.3 / \mathrm{h}$ (US\$1.27) which accounts for $24.71 \%$ of the machine cost. But the cost will vary according to the fluctuating fuel price and spare and repair rates of the machine parts. Lack of authorized repair shops and suitable after-sale services are also a reason for high repair rate and spare rates. The total cost of the machine was Rs.137.21/h (US\$1.98) for gear -1 and Rs.125.91/h (US\$1.81) for gear- 2 respectively. The harvesting cost per hectare calculated considering the field capacity was found to be Rs.1140.59/ha (US\$16.44) and Rs. 1368.61/ha (US\$19.73) for gear-1 and gear-2 respectively. It is observed for harvesting with the gear- 1 operation, and it saves the cost, which is more beneficial. The labour requirement for the machine for operating in gear- 1 and gear- 2 are 8.3 (man-h/ha) and 10.8 (man-h/ha).

Comparison of Harvesting with VCR and Manual Harvesting Methods

The self-propelled VCR was compared with conventional practices and presented in Table 8 . It was observed in the field that on an average $56 \mathrm{man}-\mathrm{h} / \mathrm{ha}$ could harvest rice crop

Table 7: Data related to the cost of rice harvesting with VCR and manual harvesting with a sickle.

\begin{tabular}{|c|c|c|c|c|}
\hline S1. No. & Observations & $\begin{array}{l}\text { Harvesting } \\
\text { (gear- 1) with VCR }\end{array}$ & $\begin{array}{l}\text { Harvesting (gear- 2) with } \\
\text { VCR }\end{array}$ & Manual harvesting (Sickle) \\
\hline 1 & Purchase value (Rs.) & 107227 & 107227 & 60 \\
\hline 2 & Machine life (years) & 15 & 15 & 10 \\
\hline 3 & Annual use (hours) & 300 & 300 & 200 \\
\hline 4 & Salvage value (Rs.)-5\% & 5361.35 & 5361.35 & 3 \\
\hline 5 & Interest rate $(\%)$ & 12 & 12 & 12 \\
\hline 6 & $\begin{array}{l}\text { Taxes, shelter and insurance ( } 2 \% \text { of purchase } \\
\text { price) }\end{array}$ & 2 & 2 & 0 \\
\hline 7 & Operator's charges, Rs./day (8h) & 335 & 335 & 235 \\
\hline 8 & Actual field capacity (ha/h) & 0.1203 & 0.092 & 0.017857 \\
\hline 9 & Fixed cost & & & \\
\hline 10 & Depreciation (R.s/year & 6791.04 & 6791.04 & 5.70 \\
\hline 11 & Interest (Rs./year) & 6755.30 & 6755.30 & 3.78 \\
\hline 12 & Shelter and insurance (Rs./year) & 1125.88 & 1125.88 & 0 \\
\hline 13 & Total fixed $\operatorname{cost}(\mathrm{Rs} / \mathrm{h})$ & 48.91 & 48.91 & 0.05 \\
\hline \multirow[t]{2}{*}{14} & Variable cost & & & \\
\hline & Fuel (Rs./h) & 42.68 & 31.65 & 0.00 \\
\hline 15 & Oil and lubricants (Rs./h) & 1.06 & 0.79 & 0.00 \\
\hline 16 & Repair and Maintenance (Rs./h) & 2.69 & 2.69 & 0.00 \\
\hline 17 & Operator charges (Rs/h) & 41.88 & 41.88 & 29.38 \\
\hline 18 & Total variable cost (Rs./h) & 88.31 & 77.01 & 29.38 \\
\hline 19 & Total cost $($ Rs./h) & 137.21 & 125.91 & 29.42 \\
\hline 20 & Cost of harvesting (Rs./ha) & 1140.59(US\$16.44) & 1368.61(US\$19.73) & 1647.67(US\$23.75) \\
\hline
\end{tabular}




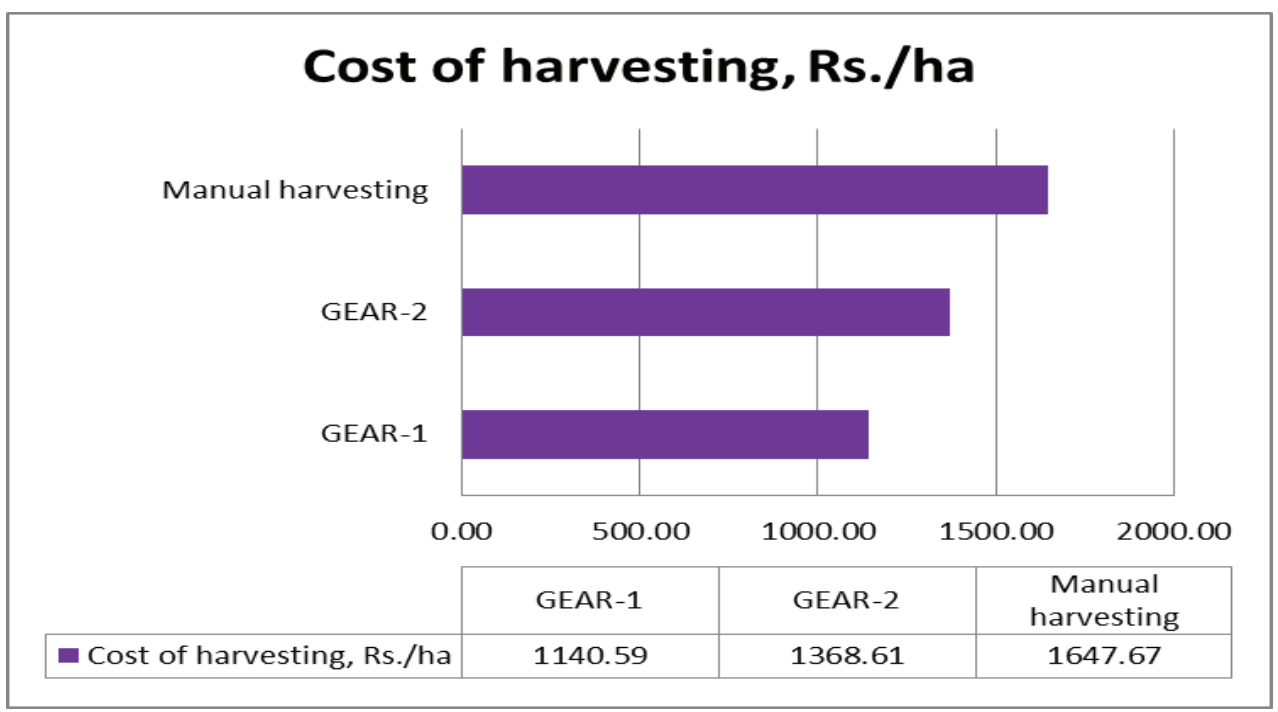

Fig. 5: Bar graph showing the cost of harvesting, (Rs/ha) for the machine (gear-1 and gear-2) and manual harvesting.

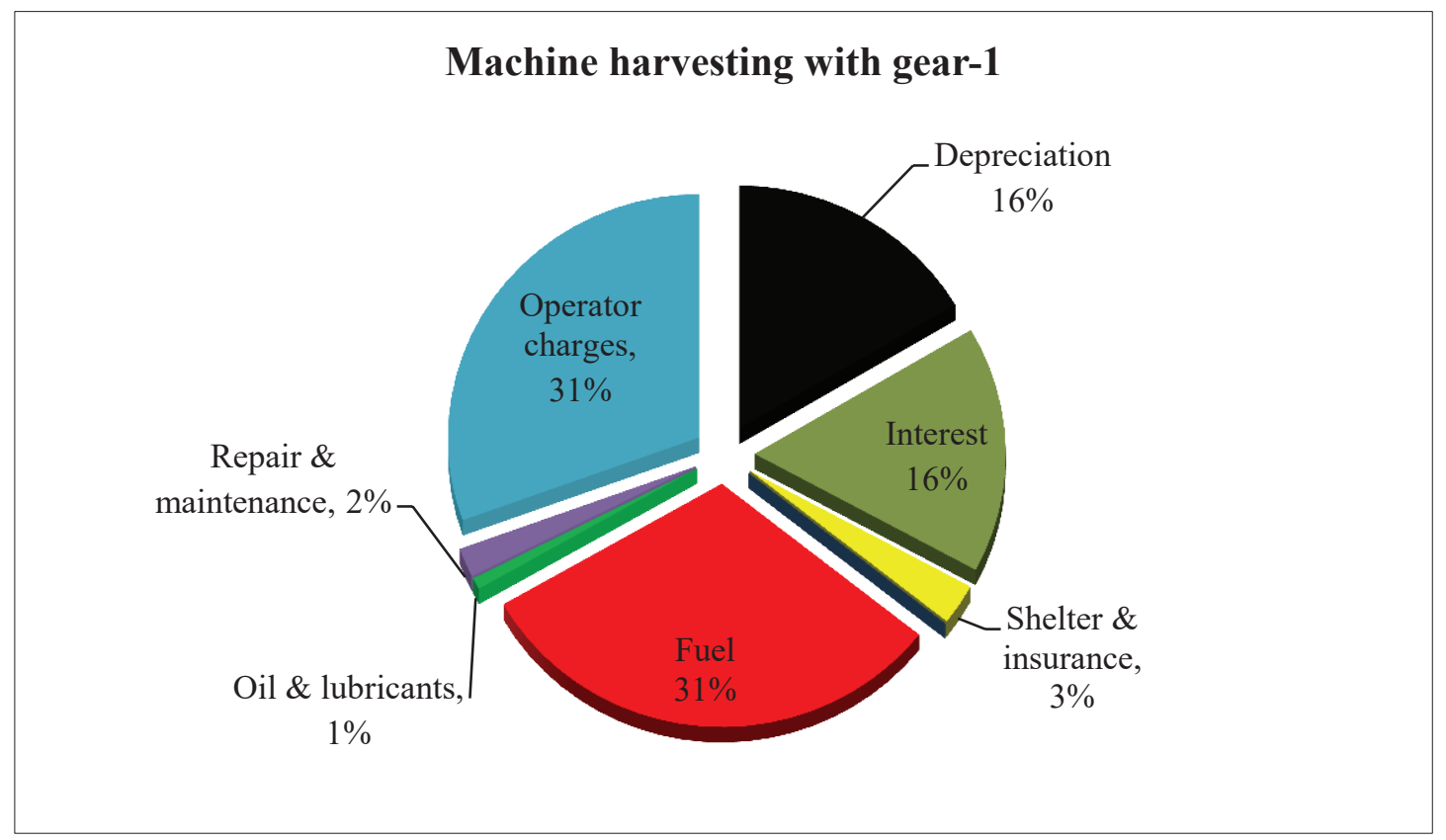

Fig. 6: Comparison of fixed cost and variable cost for gear-1 operation.

manually with the sickle. The use of VCR lead to considerable savings in time and labour was found $85.2 \%$ (Gear 1) and $80.6 \%$ (Gear 1) higher than that of manual harvesting method and could save 30.8 and $16.9 \%$ of the cost of operation in gear-1and gear-2 respectively.

Based on the study it is evident that the use of VCR is certainly helpful in saving time, labour, and cost of the harvesting operation. The lower speed of operation is recom- mended for better operational control of the machine during the harvesting operation. However, this machine cannot be operated in the terraces having a width less than $4 \mathrm{~m}$.

Total Crop Residue Generation and Amount of Proportion Burnt in Indian Agricultural Fields

The total crop residue generated in India was calculated using Eggleston (2006) guidelines based on annually crop production data acquired from the Department of Agriculture 


\section{Machine harvesting with gear-2}

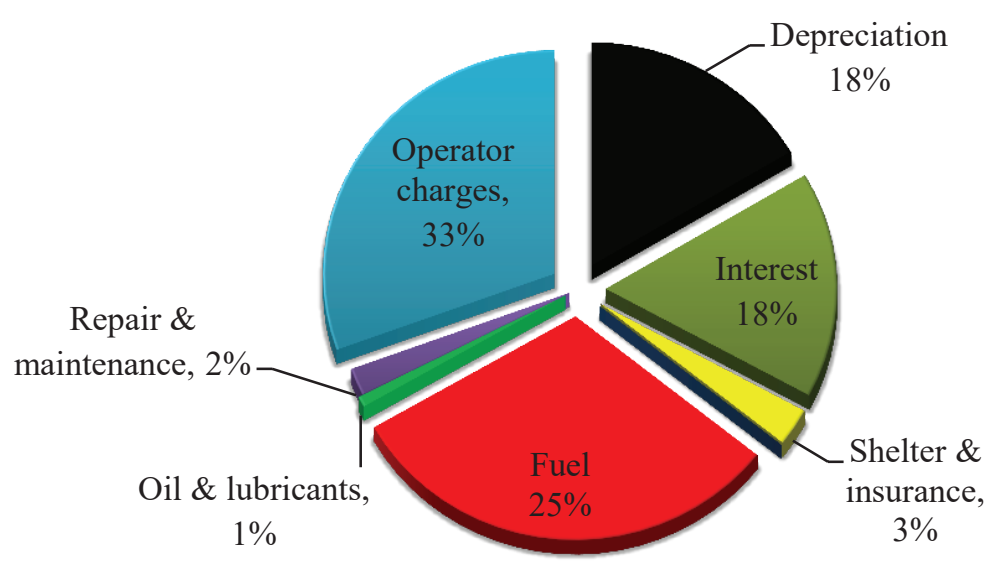

Fig. 7: Comparison of fixed cost and variable cost for gear-2 operation.

(2018) (Ravindra et al. 2019a). Sowing window between the harvesting of Kharif crops, and rabi crops are very short are one of the major causes that farmers prefer to burn residue in agriculture fields (Ravindra et al. 2019a). As can be observed from Table 9, crop production has increased from $476 \mathrm{MT}$ to 618 MT since 2003-04 to 2016-17. Table 10 shows the comparative overview of crop residue burning in India.

\section{Crop Residue Generated by Harvesting with VCR Implement and its Benefits}

The plant heights of the crop in terrace 1 and terrace 2 were 850 to $1250 \mathrm{~mm}$ and 700 to $900 \mathrm{~mm}$ respectively. As per Table 11, the average plant height of paddy crop in terrace 1 and terrace 2 was $1020 \pm 210 \mathrm{~mm}$ and $790 \pm 100.02 \mathrm{~mm}$ respectively. But after harvesting with VCR the stubble height in terrace 1 and terrace 2 were $15 \pm 8 \mathrm{~mm}$ and $21 \pm 3 \mathrm{~mm}$ respectively, which is $50 \mathrm{~mm}$ shorter than manual harvesting in both terraces. The plant height in second terrace slightly higher due to VCR operated at $2^{\text {nd }}$ gear.

VCR harvested crop produces very less amount of stub- ble which is neither required to burn in the field for sowing next crop. It is because the cutter bar is operated in the field at a height of $1.2 \mathrm{~mm}$. 15-21 mm of average stubble can be easily degraded on the field by in-situ methods, which can lead to enrichment of soil for the next crop. Besides, manual harvesting leaves a gap for cutting of stubbles which needs labour and puts a huge pressure farmer due to increasing wage rates. Also, after cutting no availability of storage facilities and proper market to sell the crop residue.

Harvesting with VCR leaves rare possibilities of burning crop residues by the farmers and subsequently, it reduces the possibility of air pollution and pollutant dispersion in the atmosphere. VCR can be used as a technological solution to reduce biomass burning in paddy fields.

\section{Available Options for Mitigation of After Harvested Crop Residue Burning Pollution}

There are various available tech and non-technological based residue burning mitigation options, which will help to reduce air pollution and GHG emissions, but also limit the adverse

Table 8: Performances with VCR for rice harvesting.

\begin{tabular}{|llll|}
\hline Sl. No. & Parameters & Gear-1 & Gear- 2 \\
\hline & Labour requirement(man-h/ha) & 8.3 & 10.8 \\
& Total cost of operation (Rs./ha) & 1140.59 (US\$16.44) & $1368.61($ US\$19.73) \\
& Time and labour Savings (\%) & 85.2 & 80.6 \\
& Cost savings (\%) & 30.8 & 16.9 \\
\hline
\end{tabular}


Table 9: Annual total crop production, residue generation and residue burnt scenario for all crops in India (Ravindra et al. 2019a).

\begin{tabular}{|llll|}
\hline Year & Crop Production (P) (in MT) & Crop Residue Generated (in MT) & Residue Burnt (in MT) \\
\hline $2003-04$ & 476.79 & 375.84 & 89.60 \\
$2004-05$ & 464.44 & 356.27 & 86.39 \\
$2005-06$ & 522.84 & 383.65 & 92.56 \\
$2006-07$ & 602.98 & 411.89 & 97.25 \\
$2007-08$ & 615.13 & 433.02 & 102.59 \\
$2008-09$ & 552.87 & 422.34 & 101.07 \\
$2009-10$ & 541.49 & 400.39 & 96.37 \\
$2010-11$ & 626.87 & 454.02 & 107.27 \\
$2011-12$ & 658.15 & 480.37 & 112.86 \\
$2012-13$ & 637.06 & 472.79 & 111.90 \\
$2013-14$ & 658.14 & 487.82 & 115.14 \\
$2014-15$ & 649.78 & 468.54 & 111.02 \\
$2015-16$ & 632.26 & 462.39 & 110.05 \\
$2016-17$ & 618.97 & 487.71 & 116.82 \\
\hline
\end{tabular}

Table 10: Comparative overview of crop residue burning estimates for India (Ravindra et al. 2019a).

\begin{tabular}{|lll|}
\hline Year & Crop residue burned (MT) & References \\
\hline Mid-90s & 84 & Streets et al. (2003a, b) \\
2001 & $116(58-289)$ & Venkataraman et al. (2006) \\
$2008-09$ & 98 & Jain et al. (2014) \\
2010 & 63 & Sahai et al. (2011) \\
$2016-17$ & 116 & Ravindra et al. (2019a) \\
\hline
\end{tabular}

Table 11: Manual and VCR harvesting crop residue height.

\begin{tabular}{|llll|}
\hline S. No. & Parameters & Observations & \\
\hline 1. & Crop variety & Panth 12(PD-12) & \\
& & Observations & \\
2. & Field plots & First terrace & $700-900$ \\
3. & Plant height $(\mathrm{mm})$ & $850-1250$ & $790 \pm 100.02$ \\
4. & Average plant height $(\mathrm{mm})$ & $1020 \pm 210$ & \\
5. & Average Stubble Height & Observations & Second terrace \\
6. & (After Harvesting) & First terrace & $69 \pm 3.6$ \\
7. & Manual Harvesting & $70.3 \pm 5.7$ & $21 \pm 3$ \\
\hline
\end{tabular}

impacts of climate change. Also, these technologies can convert residue into daily usable energy and ameliorated field products.

Crop residues in biomass-based energy generation: Crop residues contain lignocellulosic biomass which meets the needs of production of alternate energy through gasification, bio methanation, and ethanol generation is one of the technological mitigation options for air pollution (Ravindra et al. 2019a, Lohan et al. 2018, Shafie 2016). According to reports, around 500 biomass power and cogeneration plants have been installed in India by the Ministry of New and Renewable Energy which generates $11.5 \%$ of the total renewable power supply (Ravindra et al. 2019a, MNRE 2016, Energy statistics 2017). Crop residue can also be used to 
produce biofuels as compatible energy for new generating vehicles in an environment-friendly, and cost-effective way.

Biochar and composting: Paddy residue could be used for formulating useful products viz. making compost, organic manure and biochar to improve soil health, soil fertility (Lohan et al. 2018). Uses of vermicompost and biochar in agricultural practices is a sustainable environmental friendly alternative, which could also help to mitigate climate change as it helps in carbon sequestration (Ravindra et al. 2019a).

Promote farm-implements with subsidy: Higher subsidy rate to farmers on farm implements and chemical fertilizers who retain their residue in the field could lead to decrease the crop residue burning pollution (Lohan et al. 2018). Resource conservation technologies (RCTs) based farm machinery such as a Zero-till seed-cum-fertilizer drill, Happy seeder, Straw chopper, Hay rakes, Straw reaper, Super straw management system, Balers and others could provide a better way to control paddy residues for improving soil health, productivity, reducing pollution to achieve sustainable agriculture (Jat et al. 2009, Palma et al. 2014, Lohan et al. 2018).

In-situ incorporation: By retention of crop residues increases soil temperature in winter through reducing upward heat flux and decreases in summer due to shading effect (Pathak et al. 2011, Lohan et al. 2018). Enhanced decomposition transforms combine harvested residues to advance nutrients and also several positive impacts and health attributes such as $\mathrm{pH}$, organic carbon, infiltration rate, higher $\mathrm{C}$ : $\mathrm{N}$, and soil alkalinity, hydraulic conductivity, microbial biomass, cation exchange capacity (CEC) and water holding capacity in the soil (Gupta et al. 2004, Gangwar et al. 2006, Kumar et al. 2015, Lohan et al. 2018). Crop residues, particularly from wheat and rice crops, have a wide C:N ratio of 70:1 to 100:1. Moreover, incorporation of residue impacts denitrification rate, an abundance of denitrifier, and $\mathrm{N}_{2} \mathrm{O}$ emissions in soil (Shan \& Yan 2013) and straw mulching by mechanical means must be promoted (Lohan et al. 2018).

Promotion of hybrid seeds and use of rice straw as livestock feed: The use of hybrid seeds, which has less mature period and producing low residues, can help in sowing within the cropping interval and enforcement of rice-wheat cropping system intensification. However, alternative use of rice straw as livestock feed contains high silica, resulting in low digestibility and nutritive values ( $\mathrm{Na}$ et al. 2014, Ravindra et al. 2019a).

Education and awareness and promotion: By increasing awareness and education among farmer communities about severe impacts of crop residue burning in fields leads to air pollution and transport of pollutants in the atmosphere and promoting alternative uses of crop residues through different workshops, and training programs at the village and district level.

\section{CONCLUSIONS}

The study has been undertaken for the assessing the feasibility and performance of the VCR in laboratory condition and in Daramdin Farm for the harvesting of the rice crop and VCR as a possibility of technological mitigation for after harvesting crop residue burning resulting air pollution. Based on the study, the following conclusions may be drawn:

1. Optimum machine performance was obtained with gear1 as harvesting at this speed could help to minimize the harvesting losses and maximize the work rate (actual field capacity).

2. The effective field capacity of the VCR for rice harvesting was $0.1203 \mathrm{ha} / \mathrm{h}$ and $0.092 \mathrm{ha} / \mathrm{h}$ in terrace 1 and 2 compared to $0.0178 \mathrm{ha} / \mathrm{h}$ in manual operation.

3. The field efficiency of harvesting operations at operating speeds of $1.52 \mathrm{~km} / \mathrm{h}$ and $2.19 \mathrm{~km} / \mathrm{h}$ was found to be $72.03 \%$ and $38.50 \%$ respectively.

4. The labour requirements for VCR were 8.3 and 10.8 man-h/ha in terrace 1 and 2 as compared to 56 man-h/ ha for manual harvesting.

5. The grain losses for VCR harvesting were $3.53 \%$ and $4.11 \%$ in both the terraces.

6. As the fixed cost is considerable (35.7\%), the machine may be promoted for its use on the custom-hire basis to make the venture economically viable.

7. Based on the study, it may be concluded that use of the machine may lead to considerable savings in time $(85.2 \%)$, labour $(80.6 \%)$ and cost (30.8\%) of harvesting, as compared to manual harvesting methods. Therefore, in terraces where the use of reaper is feasible, its use may be promoted.

8. During the harvesting of paddy crop, the crop stem cuts at an average height of 15-21 mm which leaves shorter residues in the field by this Vertical conveyor reaper.

9. Harvesting paddy with VCR reduces the possibility of air pollution by stubble burning in atmosphere and dispersion of pollutants.

10. The small amount of crop residues left after harvesting enrich the soil for next crop, also further recovery of residue can be used for biocomposting, bioenergy, etc.

\section{ACKNOWLEDGEMENT}

The authors are sincerely thankful to Department of Farm Machinery and Power Engineering, College of Agricultural 
Engineering and Post Harvest Technology (Central Agricultural University, Imphal), Ranipool, Sikkim, India and Food Security and Agriculture Development Department for cooperation and providing such facilities in Daramdin farm to carryout field evaluation.

\section{REFERENCES}

Alizadeh, M.R., Bagheri, I. and Payman, M.H. 2007. Evaluation of a rice reaper used for rapeseed harvesting. American-Eurasian J. Agric. \& Environ. Sci., 2: 388-394.

Andreae, M.O. 1991. Biomass burning: Its history, use, and distribution and its impact on environmental quality and global climate. In: Levine, J.S. (Ed.), Global Biomass Burning, Atmospheric, Climatic, and Biospheric Implications. MIT Press, Cambridge, MA, pp. 3-21.

Andreae, M.O. and Merlet, P. 2001. Emission of trace gases and aerosols from biomass burning. Global Biogeochemical Cycles, 15(4): 955-966.

Awasthi, A., Agarwal, R., Mittal, S.K., Singh, N., Singh, K. and Gupta, P.K. 2011. Study of size and mass distribution of particulate matter due to crop residue burning with seasonal variation in rural area of Punjab. India. J. Environ. Monit., 13(4): 1073-1081.

Badr, M.M. 2005. Comparative study between some different combine sizes in respect to unit plot area. M. Sc. Thesis. Agric. Eng. Dept., Faculty of Agric., Zagazig Univ. Egypt.

Bansal, R.K. and Sakr, B. 1992. Development of a vertical conveyor reaper for harvesting chickpeas and lentils in Morocco. American Society of Agricultural and Biological Engineers. 8: 425-428

Bukhari, S., Mughal, A.Q., Baloch, J.M., Malik, R.J. and Mirani, A.N. 1991. Grain losses in wheat harvested by tractor front mounted Reaper windrower. Agricultural Mechanization in Asia, Africa and Latin America, 22: 15-20.

Chen, J., Li, C., Ristovski, Z., Milic, A., Gu, Y., Islam, M.S., Wang, S., Hao, J., Zhang, H., Duan, F., Liu, X., Yu, T. and Cachier, H. 2004. Identification and estimate of biomass burning contribution to the urban aerosol organic carbon concentrations in Beijing. Atmospheric Environment, 38: 1275-1282.

Dutt, P. Prasad, J. 2002. Modification and evaluation of self-propelled reaper for harvesting soybean. Agricultural Mechanization in Asia, Africa and Latin America, 3: 43-46.

Eggleston, H.S., Buendia, L., Miwa, K., Ngara, T. and Tanabe, K. (Eds.) 2006. IPCC Guidelines for National Greenhouse Gas Inventories. National Greenhouse Gas Inventories Programme. IGES, Japan.

El-Sharbasy, M.A. 2006. Construction and manufacture a self-propelled machine suits for cutting some grain crops to minimize losses and maximize efficiency. Misr J. Ag. Eng., 23: 509- 531.

Energy Statistics 2017. Central Statistics Office Ministry Of Statistics And Programme Implementation Government Of India New Delhi http:// www.mospi.gov.in/sites/default/files/publication_reports/Energy_Statistics_2017r.pdf.pdf Accessed on 27/07/2018

FS \& ADD 2016 Annual Reports. Food Security and Agriculture Development Department, Govt. of Sikkim, India.

Gangwar, K.S., Singh, K.K., Sharma, S.K. and Tomar, O.K. 2006. Alternative tillage and crop residue management in wheat after rice in sandy loam soils of Indo-Gangetic plains. Soil Res., 88: 242-52.

Garg, I. K., Sharma, V.K. and Singh, S. 1984. A power tiller-mounted vertical conveyor reaper-windrower. Agricultural Mechanization in Asia, Africa and Latin America, 15: 41-44.

Gill, N., Dogra, R. and Dogra, B. 2018. Influence of moisture content, particle size, and binder ratio on quality and economics of rice straw briquettes. BioEnergy Research, 11: 54-68.

Godish, T. 1997. Air Quality. Lewis Publishers, Boca Raton, New York, pp. 137-178.
Gupta, P.K., Sahai, S., Singh, N., Dixit, C.K., Singh, D.P. and Sharma, C. 2004. Residue burning in rice-wheat cropping system: causes and implications. Curr. Sci., India, 87(12): 1713-5.

Guruswamy, T., Desai, S.R., Veeranagouda, M. and Barker, R.D. 1996. Performance evaluation of vertical conveyor reaper windrower. Karnataka J. Agric. Sci., 9: 102-105.

IS: 10378-1982(Reaffirmed in 2001). 2001. Specifications for Knife Back for Harvesting Machines. Bureau of India Standards, New Delhi.

IS: 11467-1985(Reaffirmed in 2012). 2012. Test Code for Cereal Harvesting Machines. Bureau of India Standards, New Delhi.

IS: 6024-1983(Reaffirmed in 1999). 1999. Specifications for Guards for Harvesting Machines. Bureau of India Standards, New Delhi.

IS: 6025-1982(Reaffirmed in 1999). 1999. Specifications for Knife Sections for Harvesting Machines. Bureau of India Standards, New Delhi.

IS: 9164-1979(Reaffirmed in 2002). 2002. Guide for estimating cost of farm machinery operation. Bureau of India Standards, New Delhi.

Jain, N., Bhatia, A., Pathak, H., 2014. Emission of air pollutants from crop residue burning in India. Aerosol Air Qual. Res., 14: 422-430

Jat, M.L., Gathala, M.K., Ladha, J.K., Saharawat, Y.S., Jat, A.S., Sharma, V.K., Kumar, V. and Gupta, R.K. 2009. Evaluation of precision land levelling and double zero-till systems in the rice-wheat rotation; water use productivity, profitability and soil physical properties. Soil Res., 105: 112-21.

Kaskaoutis, D.G., Kumar, S., Sharma, D., Singh, R.P., Kharol, S.K., Sharma, M., Singh, A.K., Singh, S., Singh, A. and Singh, D. 2014. Effects of crop residue burning on aerosol properties, plume characteristics, and long-range transport over northern India. J. Geophys. Res. Atmos., 119: 5424-5444.

Kathirvel, K., Jesudas, D.M. and Suthakar, B. 2009. Mechanical harvesting of fodder as influenced by crop, machine and operational parameters. Agricultural Mechanization in Asia, Africa and Latin America, 40: 52-56.

Kumar, P., Kumar, S. and Joshi, L. 2015. Socioeconomic and Environmental Implications of Agricultural Residue Burning: A case study of Punjab, India. Springer Briefs in Environmental Science. pp. 144. ISBN 97881-322-2014-5

Kumar, S., Singh, M. and Singh, B. R. 2013. Feasibility and economic viability of raised bed planter in western plane zone of Uttar Pradesh, India. Soil and Tillage Research, 128: 37-43.

Kurhekar, S.P. and Patil, S.R. 2011. Performance evaluation of self-propelled walking type vertical conveyor reaper. Internat. J. Proc. \& Post Harvest Technol., 2: 29-31.

Lemieux, P.M., Lutes, C.C. and Santoianni, D.A. 2004. Emissions of organic air toxics from open burning: A comprehensive review. Progress in Energy and Combustion Science, 30(1): 1-32

Levine, J.S., Cofer, W.R., Cahoon, D.R. and Winstead, E.L. 1995. Biomass burning: A driver for global change. Environmental Science \& Technology, 29(3): 120A-125A.

Lohan, S.K., Jat, H.S., Yadav, A.K., Sidhu, H.S., Jat, M.L., Choudhary, M., Peter, J.K. and Sharma, P. C. 2018. Burning issues of paddy residue management in north-west states of India. Renewable and Sustainable Energy Reviews, 81: 693-706.

Manjunatha, M.V., Reddy, B.G.M., Shashidhar, S.D. and Joshi, V.R. 2009. Field performance evaluation of vertical conveyor paddy reaper. Karnataka J. Agric. Sci., 22: 140-142.

McCarty, J.L., Korontzi, S., Justice, C.O. and Loboda, T. 2009. The spatial and temporal distribution of crop residue burning in the contiguous United States. Sci. Total Environ., 407(21): 5701-5712

McNeill, V.F. 2017. Atmospheric aerosols: clouds, chemistry, and climate. Annual Rev. Chem. Biomol. Eng., 8: 427-444.

Ministry of New and Renewable Energy (MNRE) 2016. http://mnre. gov.in/schemes/gridconnected/ biomass-powercogen/. Accessed on $27 / 07 / 2018$ 
Mittal, S.K., Singh, N., Agarwal, R., Awasthi, A. and Gupta, P.K. 2009. Ambient air quality during wheat and rice crop stubble burning episodes in Patiala. Atmospheric Environment, 43(2): 238-244.

Mohanraj, R. and Azeez, P.A. 2004. Health effects of airborne particulate matter and the Indian scenario. Current Science, 87(6): 741-748.

Na, Y.J., Lee, I.H., Park, S.S. and Lee, S.R. 2014. Effects of combination of rice straw with alfalfa pellet on milk productivity and chewing activity in lactating dairy cows. Asian-Australas. J. Anim. Sci., 27: 960-964

Nadeem, A. and Gee-Clough, D. 1983. Field performance evaluation of rice reaper. Agricultural Mechanization in Asia, Africa and Latin America, 14: 35-40.

Nadeem, M., Iqbal, M., Farooque, A., Munir, A., Ahmad, M. and Zaman, Q. 2015. Design and evaluation of self-propelled reaper for harvesting multi crops. ASABE Annual International Meeting, pp. 1-7.

Palma, C., Humberto, B.C., DeClerckc, F., Gaterea, L. and Grace, P. 2014. Conservation agriculture and ecosystem services: an overview. Agr. Ecosyst Environ., 187: 87-105.

Pandey, J.S., Kumar, R. and Devotta, S. 2005. Health risks of $\mathrm{NO}_{2}$, SPM and $\mathrm{SO}_{2}$ in Delhi (India). Atmospheric Environment. 39(36): 6868-6874.

Pathak, H., Saharawat, Y.S., Gathala, M. and Ladha, J.K. 2011. Impact of resource conserving technologies on productivity and greenhouse gas emissions in the rice-wheat system. Greenhouse Gases. Sc. Tech., 1(3): 261-77.

Prasad, J., Devnani, R.S. and Datt, P. 1992. Evaluation of vertical conveyor reaper for harvesting safflower crop. Indian Journal of Agricultural Engineering, 2: 229-233.

Ramanathan, V., Chung, C., Kim, D., Bettge, T., Buja, L., Kiehl, J.T., Washington, W.M., Fu, Q., Sikka, D.R. and Wild, M. 2005. Atmospheric brown clouds: impacts on South Asian climate and hydrological cycle. Proc. Natl. Acad. Sci. Unit. States Am., 102(15): 5326-5333.

Ravindra, K., Sidhu, M.K., Mor, S., John, S. and Pyne, S. 2016a. Air pollution in India: bridging the gap between science and policy. J. Hazardous, Toxic, Radioact. Waste., 20(4): A4015003-10

Ravindra, K., Singh, T. and Mor, S. 2019a. Emissions of air pollutants from primary crop residue burning in India and their mitigation strategies for cleaner emissions. Journal of Cleaner Production, 208: 261-273.

Ravindra, K., Singh, T., Mor, S., Singh, V., Mandal, T. K., Bhatti, M. S., Gahlawat, S.K., Dhankhar, R. and Beig, G. 2019b. Real-time monitoring of air pollutants in seven cities of North India during crop residue burning and their relationship with meteorology and transboundary movement of air. Sci. Total Environ., 690: 717-729.

Sahai, S., Sharma, C., Singh, S.K. and Gupta, P.K. 2011. Assessment of trace gases, carbon and nitrogen emissions from field burning of agricultural residues in India. Nutrient Cycl. Agroecosyst., 89: 143-157.

Schwartz, J. 1993. Particulate air pollution and chronic respiratory disease. Environmental Research, 62(1): 7-13.

Sen, A., Abdelmaksoud, A.S., Nazeer Ahammed, Y., Alghamdi, M.., Banerjee, T., Bhat, M.A., Chatterjee, A., Choudhuri, A.K., Das, T., Dhir, A., Dhyani, P.P., Gadi, R., Ghosh, S., Kumar, K., Khan, A.H., Khoder, M., Maharaj Kumari, K., Kuniyal, J.C.Kumar, M., Lakhani, A., Mahapatra, P.S., Naja, M., Pal, D., Pal, S., Rafiq, M., Romshoo, S.A., Rashid, I., Saikia, P., Shenoy, D.M., Sridhar, V., Verma, N., Vyas, B.M., Saxena,
M., Sharma, A., Sharma, S.K. and Mandal, T.K. 2017. Variations in particulate matter over Indo-Gangetic Plains and Indo-Himalayan Range during four field campaigns in winter monsoon and summer monsoon: Role of pollution pathways. Atmos. Environ., 154: 200-224.

Shafie, S.M. 2016. A review on paddy residue based power generation: Energy, environment and economic perspective. Renew. Sustain. Energy Rev., 59: 1089-1100.

Shan, J. and Yan, X. 2013. Effects of crop residue returning on nitrous oxide emissions in agricultural soils. Atmos Environ., 71:170-5.

Singh, L.P., Vagadia, V.R., Jain, K.K. and Menon, A. H. 2008. Evaluation and improvement in design of self-propelled vertical conveyor reaper. Agricultural Mechanization in Asia, Africa and Latin America, 39: 34-38.

Singh, S., Vatsa, D.K. and Verma, M.K. 2007. Feasibility and performance evaluation of power tiller operated reaper in hills of Himachal Pradesh. Agricultural Engineering Today, 31: 6-10.

Streets, D.G., Bond, T.C., Carmichael, G.R., Fernandes, S.D., Fu, Q., He, D., Klimont, Z., Nelson, S.M., Tsai, N.Y., Wang, M.Q., Woo, J.H. and Yarber, K.F. 2003a. An inventory of gaseous and primary aerosol emissions in Asia in the year 2000. J. Geophys. Res. Atmos., 108(D21): 30-1-30-23, 8809

Streets, D.G., Yarber, K.F., Woo, J.H. and Carmichael, G.R. 2003b. Biomass burning in Asia: Annual and seasonal estimates and atmospheric emissions. Global Biogeochem. Cycles, 17(4): 10-1 -10-20, 1099.

Thaller, E., Hollaway, L., Mai, V., Hochman, D., Bharti, B., Brooks, E., Petronella, S. 2004. Air pollution and pulmonary function. Journal of Allergy and Clinical Immunology, 113(2): S65

Tripathi, A., Mishra, B.P., Kumar, M. and Patre, N.K. 2018a. Field Performance of Machine for Harvesting of Wheat and Linseed. Int. J. Pure App. Biosci., 6: 1512-1519.

Tripathi, A., Mishra, B.P., Kumar, M., Thakur, Y.S. and Mahilang, K.K.S. 2018b. Performance evaluation of reaper-cum-binder for harvesting of soybean and rice. Int. J. Curr. Microbiol. App. Sci., 7: 1754-1762.

Venkataraman, C., Habib, G., Kadamba, D., Shrivastava, M., Leon, J.F., Crouzille, B., Boucher, O. and Streets, D.G. 2006. Emissions from open biomass burning in India: integrating the inventory approach with high-resolution moderate resolution imaging spectroradiometer (MODIS) active-fire and land cover data. Global Biogeochem. Cycles, 20(2).

Venkataraman, C., Habib, G., Kadamba, D., Shrivastava, M., Leon, J.F., Crouzille, B., Boucher, O. and Streets, D.G. 2006. Emissions from open biomass burning in India: integrating the inventory approach with high-resolution Moderate Resolution Imaging Spectroradiometer (MODIS) active-fire and land cover data. Global Biogeochem. Cycles 20: $1-12$.

WHO (World Health Organization) 2004. Systematic Review of Health Aspects of Air Pollution in Europe. WHO Regional Office for Europe. June, pp. 4-16.

Witham, C., Manning, A. 2007. Impacts of Russian biomass burning on UK air quality. Atmos. Environ., 41(37): 8075-8090.

Yang, S., He, H., Lu, S., Chen, D. and Zhu, J. 2008. Quantification of crop residue burning in the field and its influence on ambient air quality in Suqian, China. Atmospheric Environment, 42(9): 1961-1969. 